\title{
Pola Aliran Informasi antara Pekerja Lepas dengan Pimpinan di PT. Idea Creative Convex (Analisis Kasus Kirab Obor Asian Games 2018)
}

\author{
Yulius Saputra, Ahmad Junaidi \\ yulius.915150186@stu.untar.ac.id,ahmadd@fikom.untar.ac.id \\ Fakultas Ilmu Komunikasi Universitas Tarumanagara
}

\begin{abstract}
The research that the author examined about the pattern of information flow according to Masmuh in the book Organizational Communication in the Perspective of Theory and Practice. The information flow pattern described by Masmuh has 5 basic patterns. The information flow pattern is chain, wheel, $y$, circle, all channels. The subjects studied by the author are freelancers with leaders at PT. Idea Creative Convex which runs the 2018 Asian Games torch relay event. The use of many freelance workers and good work results is the focus of this research. The research method used is descriptive qualitative. The researcher collected data by observation, interviews, documents. Selected speakers represent 2 parties between the project manager and project officer as the head of the company with the head of the technical torch division, logistics as freelance workers at this company. The conclusion obtained by the researcher is the use of information flow patterns in this company using 2 patterns combined between the chain information flow pattern and the wheel information flow pattern. The pattern image of the combined pattern is similar to the tree root stem. Changes in the pattern of information flow are conditioned by interference or obstruction during the execution of the relay procession.
\end{abstract}

Keywords: Kirab Obor, Information Flow Model, Asian Games

\begin{abstract}
Abstrak
Penelitian yang penulis teliti mengenai pola aliran informasi. Pola aliran informasi memiliki lima pola dasar. Pola aliran inforamasinya adalah pola rantai, roda, y, lingkaran, semua saluran. Subjek yang diteliti oleh penulis adalah tenaga kerja lepas dengan pimpinan pada PT. Idea Creative Convex yang menjalankan acara kirab obor Asian Games 2018. Penggunaan pekerja lepas yang banyak dan hasil kerja yang baik merupakan hal yang menjadi fokus pada penelitian ini. Metode penelitian yang digunakan adalah kualitatif deskriptif. Peneliti melakukan pengumpulan data dengan observasi, wawancara, dokumen. Narasumber yang dipilih mewakilan 2 pihak antara project manager dan project officer selaku pimpinan pada perusahaan tersebut dengan kepala divisi torch technical,logistik selaku pekerja lepas pada perusahaan ini. Kesimpulan yang didapatkan oleh peneliti adalah penggunaan pola aliran informasi pada perusahaan ini menggunakan 2 pola gabungan antara pola aliran informasi rantai dengan pola aliran informasi roda. Gambaran pola dari pola gabungan tersebut mirip dengan batang akar pohon. Perubahan pola aliran informasi tersebut dikondisikan dengan gangguan atau halangan pada saat pelaksanaan acara kirab obor berlangsung.
\end{abstract}

Kata kunci: Kirab obor, Pola Aliran Informasi, Asian Games 


\section{Pendahuluan}

Komunikasi adalah suatu topik yang sangat dekat dan sangat berpengaruh kepada kehidupan manusia. Bentuk komunikasi bisa dari individu kepada individu atau kelompok kepada kelompok atau kelompok kepada individu maupun sebaliknya. Komunikasi terjadi di seluruh aspek kehidupan manusia termasuk kedalam suatu organisasi. Organisasi yang baik merupakan organisasi yang memiliki komunikasi yang sehat. Komunikasi yang ada dalam suatu organisasi merupakan komunikasi yang memberikan dampak kepada tujuan maupun hasil kerja pada organisasi tersebut, begitu juga yang dialami oleh PT. Idea Creative Convex yang juga memiliki cara berkomunikasi yang sehat pada saat melaksanakan acara kirab obor Asian Games 2018. PT. Idea Creative Convex merupakan perusahaan yang bergerak pada bidang profesional conference organizer. PT. Idea Creative Convex dipercayai oleh INASGOC selaku panitia pelaksanaan Asian Games 2018 untuk memimpin dan melaksanakan acara kirab obor Asian Games 2018.

Dari segala jenis persiapan dan kepanitian yang dilakukan oleh INASGOC membuahkan hasil yang sangat baik. INASGOC (Indonesia Asian Games 2018 Organizing Committee) adalah komite resmi yang dibentuk pemerintah Indonesia sebagai panitia pelaksana yang akan menyusun rencana, menyiapkan dan menyelenggarakan Asian Games 2018. Pada tanggal 2 Maret 2019 Sheik Ahmad Al Falah Sabah selaku Presiden Dewan Olimpiade Asia (OCA) memberikan penghargaan OCA Award yang diterima oleh Ketua Umum Olimpiade Indonesia (KOI), Erick Thohir. Keberhasilan juga dinilai dengan publikasi yang begitu masif, publikasi yang begitu masif tersebut disebabkan oleh euforia yang begitu masif juga. Cara INASGOC memeperkenalkan event Asian Games 2018 salah satunya dengan melakukan kirab obor. Kirab obor Asian Games 2018 dipercayakan kepada PT. ICC (Idea Creative Convex) setelah dilakukannya pitching oleh pihak INASGOC. Kirab obor adalah salah satu budaya olimpiade secara internasional. Kirab obor Asian Games 2018 melibatkan 2 unsur api yaitu api dari India tepatnya di ambil dari India dan api abadi yang berada di Mrapen, Jawa Tengah. Kedua api tersebut dipersatukan di Candi Prambanan pada tanggal 18 Juli 2018. Setelah api tersebut digabungkan maka jadilah api abadi Asian Games 2018. Api tersebut diletakan pada lentera khusus yang disebut Tinder box. Obor tersebut diarak ke 50 titik di seluruh Indonesia. Titik yang dipilih merupakan titik-titik pariwisata yang ada di Indonesia. Tujuan pemilihan titik tersebut adalah untuk memperkenalkan serta mempromosikan bidang pariwisata yang ada di Indonesia. Event tersebut dilaksanakan selama 40 hari. Dalam melaksanakan event selama 40 hari di lapangan yang sangat amat menguras tenaga fisik dan psikologis sehingga PT. ICC menjaga kinerja para pekerjanya dengan berbagai cara. Sebelum dilaksanakannya event tersebut PT. ICC melakukan dengan cara melakukan rapat dan diskusi secara berkala dengan durasi kurang lebih 2 minggu 1 kali dan 1 minggu sekali pada saat 30 hari sebelum pelaksanaan.

Alasan penulis tertarik pada penelitian ini adalah PT. Idea Creative Convex (ICC) melaksanakan acara kirab obor Asian Games 2018 melibatkan banyak pekerja lepas namun tetap bisa memberikan hasil akhir yang sangat memuaskan. 


\section{Metode Penelitian}

Jenis dan pendekatan penelitian yang digunakan adalah kualitatif deskriptif. Penelitian kualitatif menurut Imam Gunawan adalah menganalisa cara berfikir induktif dengan perubahan hubungan antar fenomena yang diteliti, logika ilmiah sangat digunakan dalam penelitan kualitatif.

Penelitian berjenis kualitatif deskriptif ini dimaksudkan untuk mendapatkan informasi mengenai pola aliran informasi antara pekerja lepas dan pimpinan pada PT. Idea Creative Convex (ICC). Adanya penelitian ini berfokus pada saat melaksanakan acara kirab obor Asian Games 2018.

Metode pengumpulan data yang digunakan pada penelitian ini adalah observasi,wawancara, dokumen. Narasumber yang peneliti wawancara ada 4 orang diantaranya 2 orang pimpinan dari PT.ICC dan 2 orang dari pekerja lepas.

Narasumber pada penelitian ini yakni Debora Sharon selaku project manager; Rangga Perdhana Putra selaku project officer; Jaka Kuniawan selaku kepala divisi torch technical(pekerja lepas); dan Kelvin Sandi sekali kepala divisi logistik(pekerja lepas)

\section{Hasil Temuan}

Masmuh (2008:57) mengungkapkan bahwa pola aliran informasi dalam organisasi bisa dilihat dari dua perspektif. Pertama, kelompok kecil sesuai dengan sumber daya yang dimilikinya akan mengembangkan pola komunikasi yang menggabungkan beberapa struktur jaringan komunikasi. Jaringan komunikasi ini kemudian merupakan sistem komunikasi umum yang akan digunakan oleh kelompok dalam mengiriman pesan dari satu orang ke orang lainnya. Kedua, jaringan komunikasi ini bisa dipandang sebagai stuktur yang diformalkan yang diciptakan oleh organisasi sebagai sarana komunikasi organisasi. Pola aliran informasi yang umumnya kita dijumpai dalam komunikasi kelompok dan organisasi diantaranya; pola lingkaran, pola roda, pola y, pola rantai, pola semua atau bintang.

Pola roda adalah pola komunikasi yang pemimpinnya jelas dan berpusat pada pemimpinnya. Sang pemimpin diperankan sebagai orang yang dapat mengirim dan menerima pesan dari semua anggotanya, sehingga jika diantara anggota lainnya ingin berkomunikasi harus melalui pemimpinnya.

Pola rantai adalah pola komunikasi yang mirip dengan pola lingkaran hanya saja komunikasi yang dapat dilakukan oleh anggota terakhir tidak bisa ke anggota pertama. Pada pola ini pemimpin diposisikan sebagai orang yang berada ditengah.

Debora menjelaskan bahwa pola aliran informasi yang digunakan pada perusahaan ini adalah pola aliran informasi rantai. Pola aliran informasi rantai membuat Debora selaku project officer tidak bisa melakukan arahan secara langsung kepada crew. Untuk melakukan pengarahan kepada crew Debora akan melakukan komunikasi secara langsung kepada kepada divisi dan kepada divisi tersebutlah yang akan melakukan arahan secara langsung kepada crew.

Rangga juga memberikan pendapat yang sama dengan Debora yaitu pola aliran informasi yang digunakan adalah pola aliran informasi rantai. Dalam keadaan tertentu pola aliran informasi dapat berubah juga Rangga sudah menjelaskan bahwa gangguan selama pelaksanaan dapat mengubah pola aliran informasi ini. Rangga (project officer) sempat menggantikan Jaka (kepala divisi torch technical) saat Jaka sedang mengalami 
gangguan. Gangguan dalam dunia event itu sendiri bisa disebabkan oleh keadaan kesehatan, gangguan teknis akomodasi, dsb. Pada saat Rangga menggantikan Jaka maka pola aliran informasinya akan berubah menjadi pola aliran informasi roda. Rangga akan mejadi poros informasi pada saat sementara. Setelah Jaka sudah bisa kembali memimpin timnya maka Rangga akan kembali posisinya dan melepas posisi sementara tersebut serta pola aliran informasi juga ikut kembali berubah.

Samahalnya dengan Debora Kelvin menjelaskan bahwa pola aliran informasi yang digunakan pada perusahaan ini adalah pola aliran informasi rantai. Penyataan ini dapat disimpulkan bahwa pola aliran informasi yang paling utama dalam perusahaan ini adalah pola aliran informasi rantai.

Pola aliran informasi yang terdapat pada perusahaan ini adalah pola aliran informasi campuran antara pola aliran informasi rantai dengan pola aliran informasi roda. Pola campuran ini bisa terjadi karena pada saat pelaksanaan banyak hal bisa terjadi seperti ada kesalahan teknis, kondisi cuaca yang berbahaya, kondisi kesehatan yang tidak menentu. Rangga yang memiliki posisi sebagai project officer tidak seharusnya turun untuk mengatur crew secara langsung.

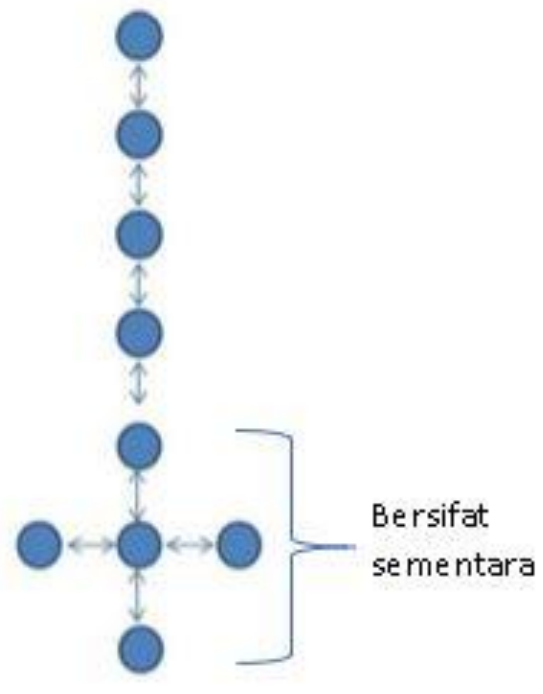

Gambar 1. Gambaran pola aliran informasi campuran antara rantai dengan roda (sementara)

\section{Elemen Organisasi}

Menurut Scoot dalam Arni (2014:25) elemen dari organisasi sangatlah bervariasi mulai dari yang sederhana sampai yang sangat kompleks. Berikut adalah elemen dasar dari suatu organisasi, diantarnya : struktur sosial, partisipan, tujuan, teknologi dan lingkingan.

Peneliti telah melakukan observasi langsung ke perusahaan maka peneliti akan menjelaskan elemen yang terdapat pada perusahaan ini diantaranya :

\section{a. Struktur sosial}

Dalam perusahaan ini struktur sosial yang peneliti bisa simpulkan terjalan dengan baik para karyawan bersikap hormat pimpinan begitu juga sebaliknya. Tidak ada ketimpangan sosial dalam perusahaan ini

\section{b. Parsipan}

Para pekerja diperusahaan ini terbagi 2 jenis diantaranya pekerja tetap dan pekerja lepas. Status pekerja lepas akan mendapatka tunjangan setiap bulannya sedangkan pekerja lepas akan dibayar sesuai dengan project. 


\section{c. Tujuan}

Tujuan yang ada pada perusahaan ini berjalan dengan baik. Seluruh pekerja memiliki tujuan yang sama yaitu tujuan untuk mencapai suatu keberhasilan acara.

\section{d. Teknologi}

Pada perusahaan ini peneliti melihat banyaknya penggunaan teknologi dalam mempersiapkan dan menjalankan suatu acara. Yang paling sangat terlihat jelas adalah banyaknya alat komunikasi HT (handytalky) yang dimiliki oleh perusahaan ini.

\section{e. Lingkungan}

Dalam elemen lingkungan sosial peneliti melihat lingkungan sosial yang terbentuk pada perusahaan ini sangatlah sehat. Kebersamaan sangat bisa dirasakan. Para pekerja sering bertukar pikiran dengan baik .

Elemen Organisasi pada perusahaan ini berfokus pada tujuan, lingkungan, teknologi.

\section{Simpulan}

Elemen organisasi yang menjadi pusat perhatian pada PT. Idea Creative Convex(ICC) adalah tujuan, lingkungan dan teknologi. Teknologi yang dimaksudkan adalah alat komunikasi. Penggunaan HT dan penggunaan aplikasi diponsel pintar seperti whatsapp. Panuju menemukan bahwa gaya komunikasi yang merespon dengan agresif akan menghasilkan komunikasi yang baik.

Pola aliran informasi yang digunakan antar pekerja lepas dengan pimpinan pada PT.ICC saat melaksanakan acara kirab obor Asian Games 2018 adalah pola aliran informasi campuran. Pola aliran infomasi campuran tersebut terbentuk dari pola aliran informasi rantai dengan roda. Pola aliran campuran tersebut bersifat sementara atau kondisional.

\section{Ucapan Terima Kasih}

Penelitian ini bisa terlaksana dengan baik karena adanya dukungan dari narasumber yang telah memberikan kesempatan kepada peneliti untuk melakukan wawancara. Narasumber yang dimaksudkan adalah Debora Sharon selaku project manager yang telah meluangkan waktunya dan berbagi pengalaman seputar dunia event; Rangga Perdhana Putra selaku project officer yang telah melungankan waktunya serta membagi pengalaman dalam berorganisasi; Jaka Kurniawan selaku pekerja lepas yang bersedia meluangkan waktu untuk melakukan wawancara melalui videocall dan yang terakhir kepada Kelvin Sandi selaku pekerja lepas yang bersedia meluangkan waktu untuk melakukan wawancara.

Ucapan terimakasih juga tidak lupa peneliti ucapkan kepada Tuhan Yesus yang telah memberikan berkat yang tiada akhir dan juga kepada Ahmad Junaidi S.S., M.Si. selaku dosen pembimbing penulis yang telah memberikan kesempatan dan ilmu pengetahuan kepada penulis. Dan ucapan terima kasih juga penulis ucapkan kepada sahabat-sahabat penulis di Fikom Untar dan teman terbaik penulis.

\section{Daftar Pustaka}

A. Muri Yusuf. 2014. Metedologi Penelitian Kuantitatif, Kualitatif \& Penelitian Gabungan. Jakarta : Prenadamedia Group. 
Bateman dan Thomas. 2009. Manajemen : Kepemimpinan dan Kolaborasi dalam Dunia yang Kompetitif. Jakarta:Salemba Empat.

Dewi, Aditya Kurnia. 2016. Hubungan Komunikasi Organisasi dan Komitmen Organisasi dengan Manajemen Konflik pada Guru di Sekolah Islam Bunga Bangsa Samarinda. Jurnal Ilmu Komunikasi Universitas Mulawarman. Vol..4 No.2

Gunawan, Imam. 2014. Metode Penelitian Kualitatif : Teori dan Praktik. Jakarta : Bumi Aksara.

Hardjana, Andre. 2018. Komunikasi Organisasi: Strategi Interaksi dan Kepimimpinan.. Depok: PT. Rajagrafindo Persada

Manopo, Jirre Victori. 2014. Peran Komunikasi Organisasi dalam Membentuk Efektivitas Kerja Karyawan CV.Magnum Sign and Print Advertising Samarinda. Jurnal Ilmu Komunikasi Universitas Mulawarman.Vol.2 No.3

Muhammad, Arni. 2009. Komunikasi Organisasi. Jakarta : Bumi Aksara.

Ngalimun. 2017. Ilmu Komunikasi Sebuah Pengantar Praktis. Yogykarta : Pustaka Baru Press.

Pace, R. Wayne dan Faules, Don F. 2015. Komunikasi Organisasi Strategi Meningkatkan Kinerja Perusahaan, terjemahan Deddy Mulyana. Bandung : PT Remaja Rosdakarya.

Pangestu, Michelle. 2015. Jaringan Komunikasi di The Piano Institute Surabaya. Jurnal Ilmu Komunikasi Universitas Kristen Petra Surabaya. Vol.3 No.2.

Panuju, R.,\& Narena, I.(2019). Komunikasi Organisasi Bidang Reservasi Hotel. Jurnal Komunikasi, $\quad 10(1) . \quad$ Terarsip di https://journal.untar.ac.id/index.php/komunikasi/article/view/2297

Ruliana, Poppy. 2018. Komunikasi Organisasi : Teori dan Studi Kasus. Depok: PT. RajaGrafindo Persada.

Suwatno, H. 2018. Komunikasi Organisasi Kontemporer. Bandung: Simbiosa Rekatama Media. 